\title{
Factors Contributing to the Categorization of Worst Performing Companies The Case of Protein Design Labs, Inc. (PDLI)
}

\author{
Chiaku Chukwuogor-Ndu *
}

\begin{abstract}
This paper examines the financial performance of one of the 2002 worst performing company, Protein Design Labs Inc. for the period 1993 to 2002. Findings indicate that the profitability ratios such as return on equity, return on assets and net profit margin were negative for most of the years between 1993 and 2004. The Pearson's correlation coefficient between Protein Design's net sales and $R \& D$ expenditure for the period 1993 to 2004 is .85 and is significant at 1 percent level. Between 1996 and 2004, annual expenditures on Research and Development exceeded the annual net sales. The current ratio of Protein Design ranges between 10:1 and 58:1 in 1998 and 2000 respectively. Protein Design is by far more liquid than its competitors. The Cash flow adequacy and Cash interest coverage ratios indicate that Protein Design was extremely liquid for most of the period. Cash flows from financing were responsible for healthy cash flow situation. The efficiency ratios were poor. They show that during the period, Protein Design had the lowest total asset turnover when compared to its immediate competitors such as Corixa and Medummune. Despite poor earnings generating performance, Protein Design is among the top emerging pharmaceutical companies attracting high corporate alliances and investors' confidence. With a new Chief Executive, a new President of Research and Development, and a strong balance sheet, Protein Design Labs Inc is expecting greater profitability in the future.
\end{abstract}

Key words: financial performance, worst performing, profitability, return on equity, profit margin, correlation coefficient, expenditure, current ratio, liquidity, Cash flow, coverage ratios, efficiency ratios, total asset turnover, solvency, research and development

\footnotetext{
* Department of Business Administration Eastern Connecticut State University, USA. e-mail: nduc@easternct.edu
} 


\section{Introduction}

When the Burrill Select Index of Biotechnology firms fell 6\% in February 2002, the largest decliner in the group was Protein Design Labs (PDLI) whose share price declined by 27 percent. This was amidst concerns that Protein Design's psoriasis drug, zenapax, might be shown to be ineffective. Zenapax was currently in Phase II clinical trials whose results are blinded, hence such speculation may be premature (Burrill \& Co, 2002). This drug eventually failed the clinical test (BTech Investor, 2002).

Protein Design Labs, Inc. is engaged in the discovery and development of humanized monoclonal antibodies for the treatment of various diseases. The group has licensed certain rights to first humanized antibody product, zenapax to Hoffmann-la Roche Inc. and its affiliates, which market it for the prevention of kidney transplant rejection. Protein Design Labs, Inc. is also testing zenapax for the treatment of auto immune disease. In addition, the group has several other humanized antibodies in clinical development for auto immune and inflammatory conditions such as asthma and cancer. The company is fully integrated from research through clinical development. The group holds fundamental patents in the United States, Europe and Japan for its antibody humanization technology. Numerous other pharmaceutical and biotechnology companies use this technology, many of which have licensed their patents and have agreed to pay royalties to Protein Design Labs Inc. on any sales of licensed products.

On April 7th, 2003, the group acquired EOS Biotechnology Inc. Royalties accounted for $87 \%$ of 2002 revenues and license and other, $13 \% .{ }^{1}$ With the above profile, Protein Design Labs Inc. presents as a company of immense potential. Yet it fared poorly in the stock market in 2002. Arguably 2002 was a bad year for many biotechnology, drug and pharmaceutical companies. Its share price between March and October 2001 ranged between $\$ 86.00$ and $\$ 34.00$. In the same period in 2002, it ranged between $\$ 20.00$ and $\$ 13.00$. See Figure 1 below. Prior to 2002, investors were buying and holding the shares of PDLI. Figure 2 shows the increase in volume of shares traded.

\footnotetext{
${ }^{1}$ Source: Disclosure's SEC Database in Thomson Research database, Eastern Connecticut State University.
} 
Factors Contributing to the Categorization of Worst Performing Companies The Case of Protein Design Labs, Inc. (PDLI)

Figure 1

Protein Design Labs Inc. Comparative Share Price 2001 and 2002

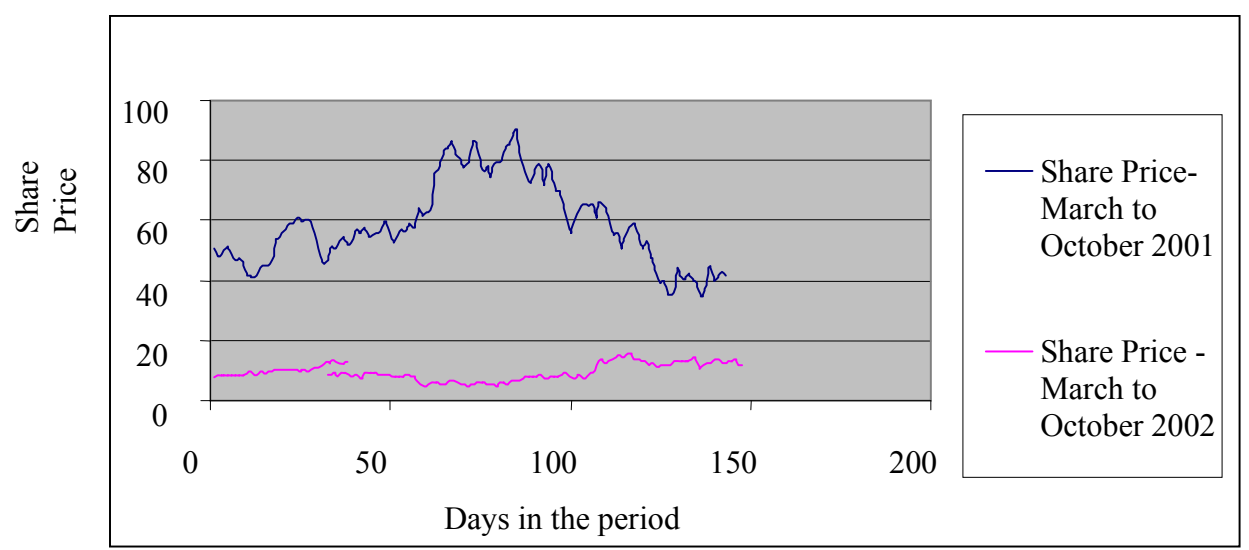

Figure 2

Protein Design Labs Inc. Share volume traded March-October 2001 \& 2002

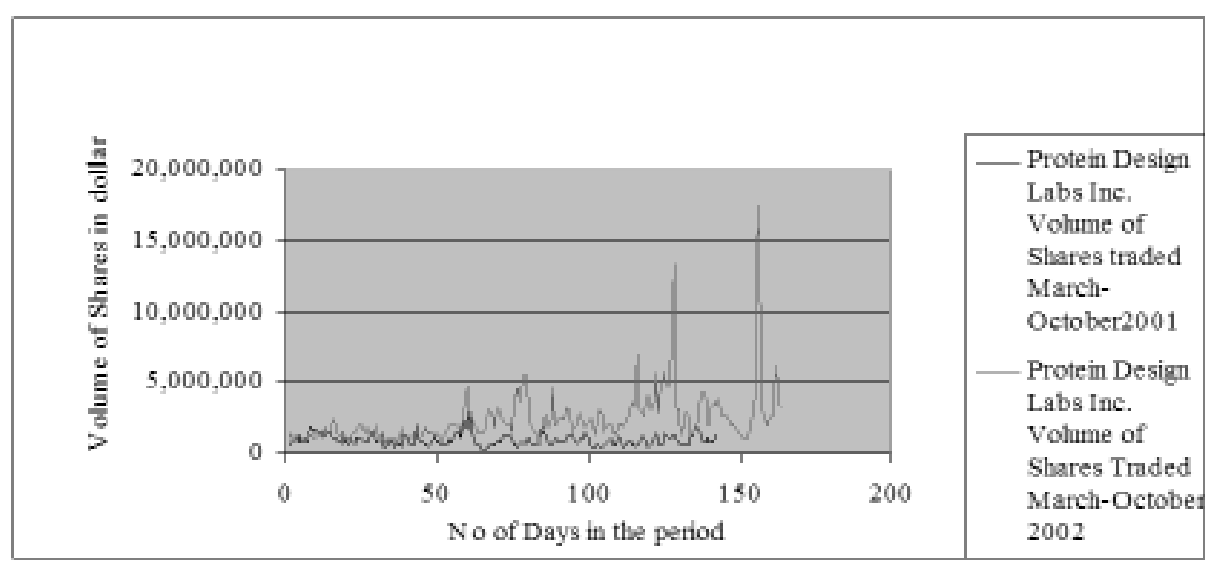

No. 217, septiembre-diciembre 2005 
The research objectives of this paper are multiple. First is to use financial and cash flows statements and any other information available to evaluate the performance of Protein Design Labs Inc. (PDLI), a poorly performing biotechnology company listed on NASDAQ to determine the reasons for its categorization as one of the worst performing companies in 2002. Secondly, to highlight the fact not often contained in Corporate Finance text books that some companies with poor financial performance can have very strong balance sheet because of investors' confidence in their future performance. Such observations should aid the teaching and conducting of financial evaluations of companies. Another reason for evaluating a pharmaceutical company, Protein Design Labs Inc. (PDLI) is because it was rated one of the worst performing companies in 2002 at a time when some drug and pharmaceutical companies were accused of enjoying supra normal profits and the possibility of price control on prescription was being discussed.

\section{Data and Methodology}

Protein Design Labs Inc. (PDLI) consolidated financial statement information available at the Disclosure SEC Database in the Thomson Research website, http://0-research.thomsonib.com.csulib.ctstateu.edu/gaportal/ga.asp and Income Statements, Balance Sheets and Cash flow Statements for the period 1993 to 2002 were used. Supplementary data such as market data were also collected from Yahoo Finance website, http://finance.yahoo.com/q?s=PDLI.

We examine the profitability, liquidity/solvency, operational efficiency and operating, investment and financing cash flows of Protein Design Labs Inc. for the period 1993-2004. We also evaluate the justification and relevance of huge expenses such as research and development expenditure. PDLI's results were compared with selected biotechnology major competitors for the years for which data is available and with the current industry average where necessary.

\section{Financial Analysis}

This analysis encapsulates time series and cross sectional analysis. The key relevant profitability, liquidity/solvency, and operational efficiency ratios for the period 1993 to 2004 are contained on Table 1 below. 
Factors Contributing to the Categorization of Worst Performing Companies

The Case of Protein Design Labs, Inc. (PDLI)

Table 1

Protein Design Labs Inc. Selected Financial Ratios 1993-2004

\begin{tabular}{cccccccc}
\hline Year & $\begin{array}{c}\text { Current } \\
\text { Ratio }\end{array}$ & $\begin{array}{c}\text { Debt } \\
\text { Ratio }\end{array}$ & $\begin{array}{c}\text { Return on } \\
\text { Assets } \\
\text { (ROA) }\end{array}$ & $\begin{array}{c}\text { Return on } \\
\text { Equity } \\
\text { (ROE) }\end{array}$ & $\begin{array}{c}\text { Earnings } \\
\text { Per Share } \\
\text { (EPS) }\end{array}$ & $\begin{array}{c}\text { Net Profit } \\
\text { Margin }\end{array}$ & $\begin{array}{c}\text { Fived } \\
\text { Asset } \\
\text { Turnover }\end{array}$ \\
\hline & & & & & & & \\
1993 & 14 & 0.03 & -0.071 & -0.08 & -0.43 & -0.40 & 0.18 \\
1994 & 30 & 0.03 & -0.043 & -0.04 & -0.34 & -0.44 & 0.10 \\
1995 & 13 & 0.03 & -0.072 & -0.07 & -0.54 & -0.73 & 0.10 \\
1996 & 15 & 0.05 & -0.11 & -0.11 & -0.75 & -0.71 & 0.15 \\
1997 & 11 & 0.04 & -0.14 & -0.14 & -1.3 & -2.14 & 0.06 \\
1998 & 10 & 0.05 & -0.06 & -0.06 & -0.51 & -0.45 & 0.12 \\
1999 & 18 & 0.01 & -0.06 & -0.06 & -0.27 & -0.39 & 0.15 \\
2000 & 58 & 0.24 & 0.0009 & 0.001 & -0.015 & 0.02 & 0.06 \\
2001 & 52 & 0.23 & 0.004 & 0.004 & 0.03 & 0.06 & 0.06 \\
2002 & 42 & 0.24 & -0.02 & -0.03 & -0.16 & -0.31 & 0.06 \\
2003 & 14 & 0.42 & -0.07 & -0.29 & -1.38 & -1.95 & 0.40 \\
2004 & 9 & 0.39 & -0.17 & -0.13 & -0.56 & -0.55 & 0.43 \\
\hline
\end{tabular}

\section{A. Profitability Analysis}

We evaluate the return on equity first using this equation:

Return on Equity $(\mathrm{ROE})=\underline{\text { Net income after tax }}$ Common equity

The return on equity (ROE) is considered to be the most important of all ratios. This is derived from the fundamental objective of the firm, which is to maximize the shareholders' wealth. The PDLI's ROE is negative for the period except in 2000 and 2001 when it was .1 percent and .4 percent respectively. To ascertain whether this observation is in accordance with industry norm, we compare the PDLI ROE with that of its major competitors Corixa Corp. and Medimmune Inc for the period 1995 to 2002. As can be seen on Figure 3, all the companies performed poorly with respect to ROE. The ROE of Corixa Corp. and Medimmune Inc fluctuated more widely. It was only between 1998 and 2001 and in 2003 that Medimmune achieved a positive ROE and outperformed Protein Design. Corixa Corp had negative ROE through out the period and deteriorated in 2004 to -3.7 . 
Figure 3

Comparative ROE: PDLI,CRXA, MEDI, 1995-2004

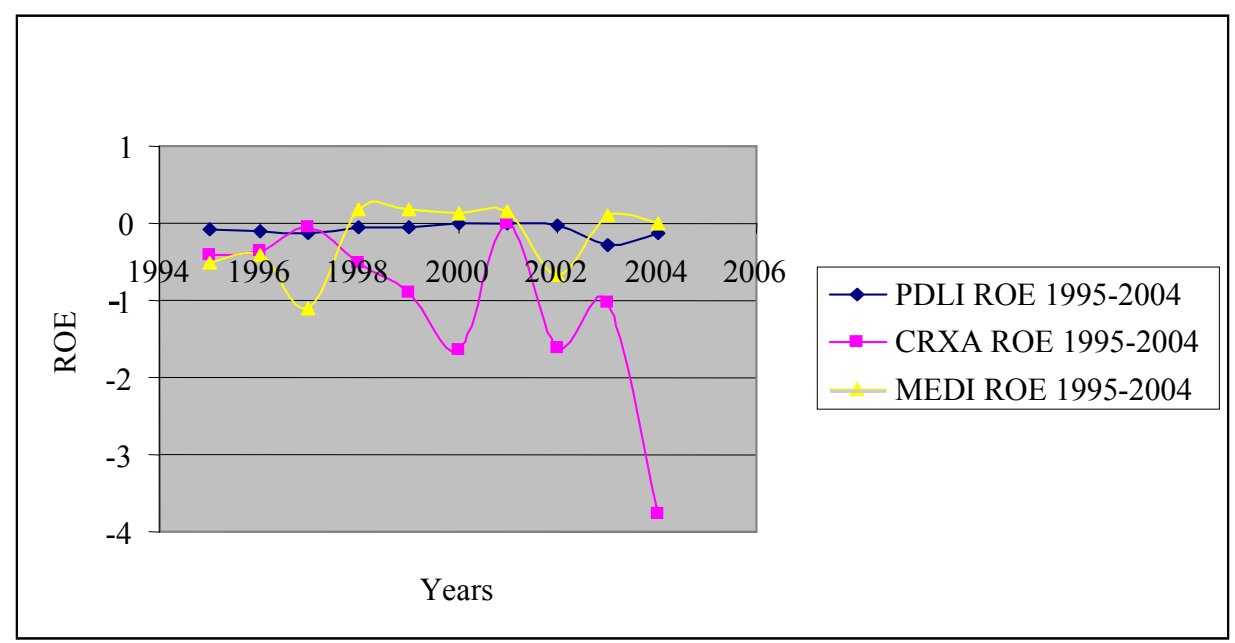

We used the Mann-Whitney U Test below, to test the equality of the PDLI's ROE with that of its major competitors Corixa Corp. and Medimmune Inc for the period 1995 to 2002.

Where $n_{1}=$ number of observations for PDLI; $n_{2}=$ number of observations for Corixa; $R_{I}=$ sum of the ranks of observations for PDLI; $R_{2}=$ sum of the ranks of observations for Corixa.

We test the hypothesis:

$H_{o}: \mu_{1}=\mu_{2} \leftarrow$ null hypothesis: There is no difference between the ROE of PDLI and Corixa, in particular, both have the same.

$H_{0}: \mu_{1} \neq \mu_{2} \leftarrow$ alternative hypothesis: There is a difference between the ROE of PDLI and Corixa, in particular, they have different means.

$\alpha=.01 \leftarrow$ level of significance for testing these hypotheses. 
We repeat this test for PDLI and Medimmune Inc. The results of the $U$ tests indicate that the difference between the ROE of PDLI and Corixa is not significant at the 1 percent level, so we accept the Null hypothesis of equality of means. However the difference between the ROE of PDLI and Medimmune Inc. is significant at the 1 percent level, so we reject the Null hypothesis and accept the Alternative hypothesis that the means are not equal.

The degree of debt in the capital structure might distort the interpretation of the ROE as companies with higher debt ratio might register higher ROE because interest expenses are tax deductible. Therefore we also analyze PDLI profitability using Return on asset (ROA).

Return on assets $=\underline{\text { Net income after tax }}$

Total assets

The ROA for the three companies for the period 1995-2004 is contained in Figure 4 below. The ROA performance is very similar to that of the return on equity and this is because the three companies have very low debt ratios.

\section{Figure 4}

\section{Comparative ROA 1995-2004}

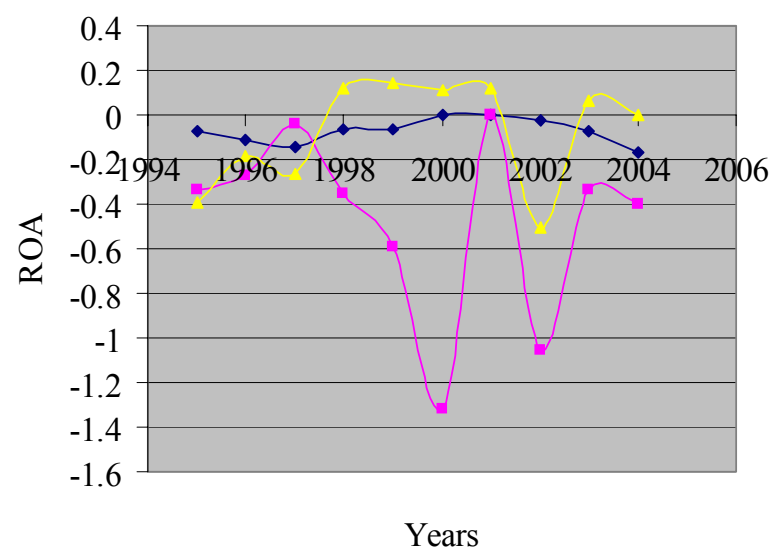

$\rightarrow$ PDLI ROA 1995-2004

$\rightarrow$ CRXA ROA 1995-2004 MEDI ROA 1995-2004 
Table 2 contains the actual calculated data for ROE and ROA for the PDLI and its immediate competitors CRXA and MEDI.

Table 2

Comparative Returns of PDLI, CRXA, MEDI, 1993-2004

\begin{tabular}{ccccccc} 
& \multicolumn{2}{c}{ Return on Assets } & & \multicolumn{2}{c}{ Return on Equity } & \\
Years & PDLI & CRXA & MEDI & PDLI & CRXA & MEDI \\
1993 & -0.071 & NA & -0.2160 & -0.08 & NA & -0.25 \\
1994 & -0.043 & NA & -0.4210 & -0.04 & NA & -0.55 \\
1995 & -0.072 & -0.3363 & -0.3954 & -0.07 & -0.40433 & -0.52 \\
1996 & -0.11 & -0.2731 & -0.1802 & -0.11 & -0.36944 & -0.41 \\
1997 & -0.14 & -0.0433 & -0.2630 & -0.14 & -0.05218 & -1.10 \\
1998 & -0.06 & -0.34839 & 0.1163 & -0.06 & -0.50531 & 0.19 \\
1999 & -0.06 & -0.59211 & 0.1440 & -0.06 & -0.90091 & 0.17 \\
2000 & 0.0009 & -1.32287 & 0.1104 & 0.001 & -1.64095 & 0.13 \\
2001 & 0.004 & -0.0004 & 0.1204 & 0.004 & -0.00053 & 0.14 \\
2002 & -0.02 & -1.05759 & -0.5018 & -0.03 & -1.61536 & -0.65 \\
2003 & -0.07 & -0.33492 & 0.0656 & -0.29 & -1.0366 & 0.11 \\
2004 & -0.17 & -0.39962 & 0.0015 & -0.13 & -3.76538 & 0.00 \\
\hline
\end{tabular}

Net profit margin indicates management's ability to operate the business with sufficient success not only to recover the cost of the merchandise or service, the expense of operating the business, and the cost of borrowed funds but also to leave a margin of reasonable compensation to the owners for putting their capital at risk (Helfert, 2000).

Net Profit margin $=$ Net profit after tax Sales

Protein Design's net profit margin shown on Table 1 was negative throughout the period except for 2000 and 2001 when it was marginally positive. The highest negative result was -2.14 in 1997. 
Research findings indicate that there is a very close relationship between the Research and Development (R \& D) pharmaceutical companies. Scherer, (2001), analyzed data on R \& D investment and profits at the aggregate industry level using Pharmaceutical Research and Manufacturers of America (PHRMA) data. The result of a time series analysis showed that the growth rate of deflated gross margins was 4.23 percent per year, much lower than the 7.51 percent growth rate found for R \& D outlays. Secondly the pharmaceutical industry's gross margins exhibit long swings around their exponential time trend. Thirdly the result of a simple Pearson's correlation between the two time series is 0.92 . At two of the three clear turning points, he finds that the $\mathrm{R} \& \mathrm{D}$ spending series precede reversals in the gross margins drive changes in $\mathrm{R} \& \mathrm{D}$ spending. With respect to Protein Design, we use the Pearson's correlation coefficient to test the relationship between the net sales and R \& D for the period 1993 to 2002 . We find that there is a high positive correlation of .85 and is significant at 1 percent level.

Between 1996 and 2004, the annual expenditures on Research and Development exceeded the annual net sales. This observation indicates huge investments in R \& Development.

\section{B. Liquidity/solvency}

A liquid firm is one that can meet its various short-term and credit obligations. Current ratio is commonly used to evaluate the debt exposure represented in the balance sheet.

$$
\text { Current ratio }=\frac{\text { Current assets }}{\text { Current Liabilities }}
$$

The current ratio of protein Design can be seen on Table 1 and it ranges between 10:1 and 58:1 in 1998 and 2000 respectively. Most Corporate Finance textbooks agree that a very common rule of the thumb suggests that a current ratio of 2:1 is right for most businesses. Why is Protein Design uncommonly liquid in spite of its poor profit performance? The total cash, cash equivalents and marketable securities are \$606.4 million, \$650.3million, and \$661.73 million in 2002, 2001 and 2000. According to the annual report 2002, these current assets primarily are derived from an active effort to license rights under their fundamental antibody humanization patents to developers of antibody based therapeutics (Protein Design, 2002). 
The resulting fees and royalties from these licenses have led to a growing revenue stream and, in turn, have reduced their cash burn. They also received upfront fees for humanizing antibodies for other companies.

Is this situation peculiar to Protein Design or is it an industry norm? According to the 2003 second Quarter June 30 report, (Multexinvestor, 2003), Protein Design's current ratio was 22.43, industry 5.17, sector 2.66 and \&P 500 1.81. Compared to its major competitors Corixa Corp. and Medimmune Inc. for the period 1993 to 2002, the current Protein Design's current ratio is very high, especially in 1994 and from 1999 to 2002. Table 3 below contains the calculate ratios for the period. The trend is depicted in Figure 5.

Table 3

Comparative Current Ratios (1993-2004)

\begin{tabular}{cccc}
\hline Years & PDLI & CRXA & MEDI \\
\hline & & & \\
1993 & 14 & N/A & 9 \\
1994 & 30 & N/A & 4 \\
1995 & 13 & 9 & 4 \\
1996 & 15 & 5 & 7 \\
1997 & 11 & 16 & 2 \\
1998 & 10 & 6 & 4 \\
1999 & 18 & 2 & 4 \\
2000 & 58 & 3 & 5 \\
2001 & 52 & 2 & 3 \\
2002 & 42 & 2 & 3 \\
2003 & 14 & 3 & 3 \\
2004 & 9 & 3 & 2 \\
\hline
\end{tabular}


Figure 5

Comparative Current Ratios 1993-2004

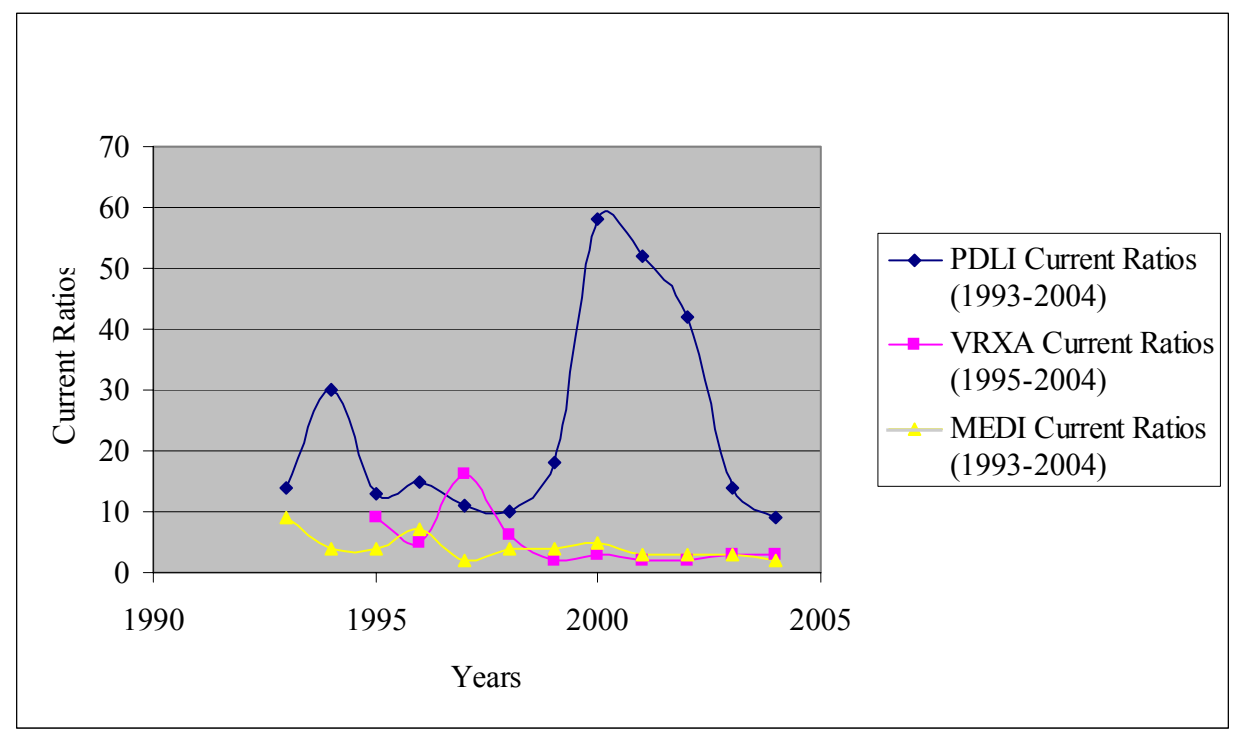

\section{Management efficiency}

The total asset turnover is one of the key ratios used to determine how efficiently a firm has used its assets in generating sales, which is a major determinant of operating income (Keown, Martin, Petty and Scott, 2003). This is a good indication of the effectiveness with which management has employed the assets entrusted to it by the shareholders. To calculate the total asset turnover for Protein Design and its competitors, we use the formula:

Total asset turnover $=$ Sales

Total assets

Table 4 below shows the total asset turnover for Protein Design Labs Inc. and its major competitors Corixa Corp. and Medimmune Inc. for the period 1995 to 2004. Figure 6 below depicts the trend. It shows that during the period, Protein Design had the lowest total asset turnover. It generated $\$ 0.095$ in sales per dollar of assets whereas Corixa generated $\$ 0.2$ and Medimmune \$0.42. Protein Design's major competitors seem to be performing poorly too. During the quarter ended on June 
31st 2003, Protein Design's total asset turnover was $\$ 0.09$; Biotechnology and Drugs industry average, $\$ 0.67$; healthcare sector $\$ 0.81$ and S \& P 500, $\$ 0.92$. The results of the $U$ test indicate that these differences are not significant even at the 1 percent level.

Table 4

Total Asset Turnover 1995-2004

\begin{tabular}{cccc}
\hline Year & PDLI & $\boldsymbol{C R} \boldsymbol{A} \boldsymbol{A}$ & $\boldsymbol{M E D I}$ \\
\hline & & & \\
1995 & 0.1 & 0.22 & 0.48 \\
1996 & 0.15 & 0.38 & 0.25 \\
1997 & 0.06 & 0.23 & 0.46 \\
1998 & 0.12 & 0.3 & 0.45 \\
1999 & 0.15 & 0.29 & 0.55 \\
2000 & 0.06 & 0.07 & 0.49 \\
2001 & 0.06 & 0.16 & 0.47 \\
2002 & 0.06 & 0.25 & 0.36 \\
2003 & 0.90 & 0.14 & 0.38 \\
2004 & 0.13 & 0.13 & 0.44 \\
\hline
\end{tabular}

Figure 6

Comparative Total Assets Turnover Ratios: PDLI, CRXA and MEDI 1995-2004

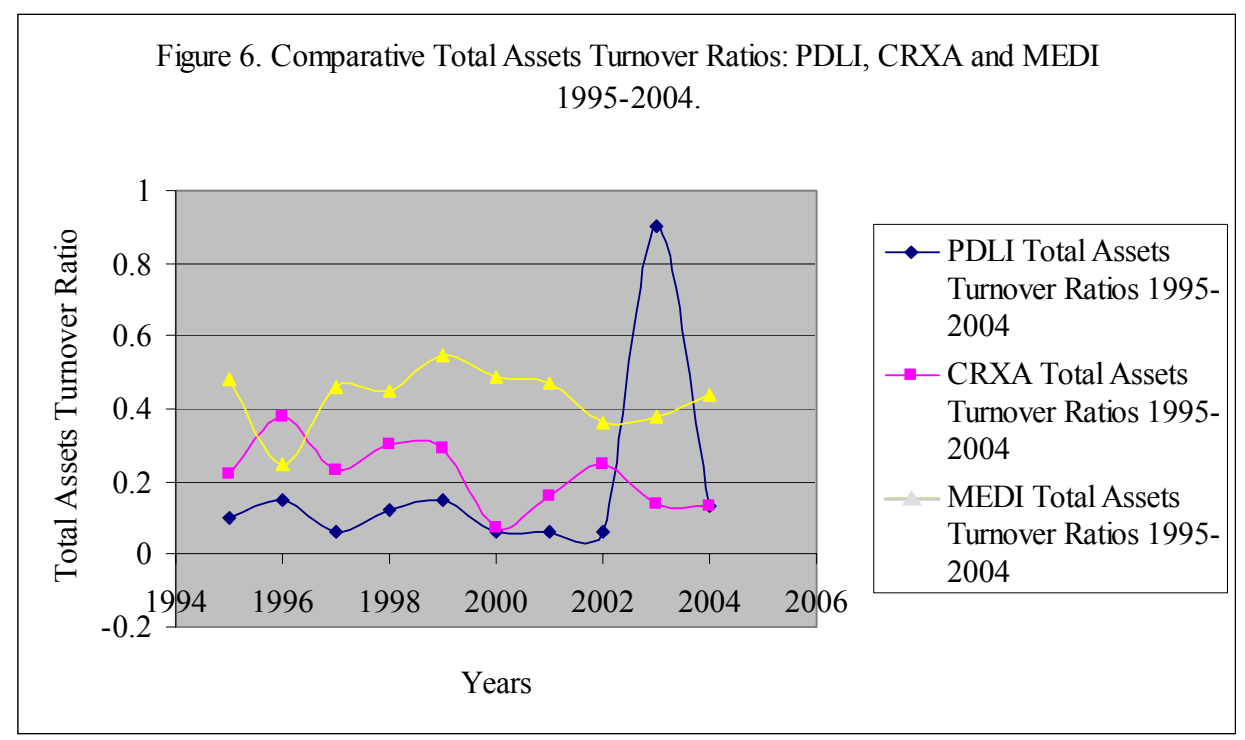


Factors Contributing to the Categorization of Worst Performing Companies

The Case of Protein Design Labs, Inc. (PDLI)

\section{Operations, Investments and financing cash flows}

Table 5 contains the net cash flow from operations, investments and financing and cash at end of period in millions of dollars for PDLI and its competitors CRXA and MEDI. Only MEDI had significant cash flow from operations since 1998. While net cash flow from investing was generally negative for all the companies, net cash flow from financing was generally positive for all the companies. It is important to note that all the companies had significant cash balances at year end

Table 5

Comparative Cash Flow in (\$millions), 1993-2004

\begin{tabular}{|c|c|c|c|c|c|c|c|c|c|c|c|c|}
\hline \multirow[b]{3}{*}{ Vears } & \multirow{2}{*}{\multicolumn{3}{|c|}{ Net Cash Flow from }} & \multicolumn{3}{|c|}{ Net Cash Flow from } & \multicolumn{3}{|c|}{ Net Cash Flow from } & \multicolumn{2}{|c|}{ Cash at Year end } & \multirow[b]{3}{*}{ MEDI } \\
\hline & & & Operations & \multicolumn{3}{|c|}{ Investing } & \multicolumn{3}{|c|}{ Financing } & & & \\
\hline & $\overrightarrow{P D L I}$ & $\bar{C} R X A$ & MEDI & $\overline{P D L I}$ & CRXA & MEDI & PDLI & CRXA & MEDI & PDLI & CRXA & \\
\hline$\overline{1993}$ & -5.4 & NA & -17.5 & -23.2 & NA & 18 & 30 & NA & 19.5 & 6 & NA & 22.2 \\
\hline 1994 & -1.9 & NA & -20.3 & -44.6 & NA & 4.1 & 46 & NA & -0.1 & 5.4 & NA & 6.4 \\
\hline 1995 & -7.1 & -3.4 & -15.9 & -4.8 & 3.9 & -8.4 & 1.5 & 48 & 32.2 & 4.7 & 3 & 14.2 \\
\hline 1996 & -7 & -2.8 & -25.8 & -11.8 & -2.7 & -0.1 & 4.7 & 4.7 & 125.4 & 14.1 & 2.1 & 12.6 \\
\hline 1997 & -7.6 & -0.3 & -54.4 & -72.1 & -30.9 & 42.8 & 74.9 & 45.6 & 42.7 & 9.3 & 16.5 & 56.6 \\
\hline 1998 & -6.5 & -7.5 & 5.1 & 21.2 & -8.5 & -97.8 & 3.9 & 8.7 & 81.1 & 27.9 & 91 & 44.7 \\
\hline 1999 & -10.7 & -5.7 & 59 & -24.9 & -16.4 & -120.7 & 24.9 & 13.8 & 54 & 17.1 & 0.8 & 36.7 \\
\hline 2000 & 6.8 & -23.7 & 173.3 & -118.2 & -30.7 & -195.6 & 515.9 & 100.7 & 74.8 & 421.5 & 47.1 & 85 \\
\hline 2001 & 2.7 & -65.8 & 250.9 & -286.3 & 50.1 & -188.2 & -17.5 & 1.9 & 23.6 & 120.3 & 33.3 & 171.2 \\
\hline 2002 & -5.1 & -45 & 263.5 & 168.9 & 9.5 & -347 & 3.8 & 49.5 & 42 & 287.7 & 47.4 & 130.1 \\
\hline 2003 & -23.6 & -53 & 357.5 & -20.9 & -92.9 & -238.3 & 98.6 & 134.9 & 266.2 & 341.8 & 36.9 & 515.5 \\
\hline 2004 & -27.2 & -591.4 & 144.7 & 240.2 & 30.3 & -300.9 & 17 & 10.5 & -187.9 & 91.4 & 18.6 & 171.3 \\
\hline
\end{tabular}

Source: Thomson Research website, http://0-research.thomsonib.com.csulib.ctstateu.edu/gaportal/ga.asp

Although Cash Flow statement (CFS) and its predecessor funds statement has been around for more than two decades, very few articles in the professional and academic journals have attempted to develop ratios based on CFS (Bhandari, 2003). A major problem in using cash flow based ratios for analyzing companies currently not making profit is that most of them focus on cash flow from operations (Carslaw \& Mills, 1991; Dennis, 1994; Giacomino \& Mielke 1988; Mills \& Yamamura, 1998; Siegel \& Akel, 1989; Zeller \& Stanko, 1994). In evaluating the cash adequacy of companies with poor earnings, emphasis should be placed on the firm's ability to raise funds either through equity issue or through issue of long-term debt securities. The investors' (creditors and shareholders) confidence in the present operational activities and future potentials is demonstrated in their willingness to invest in the continued operations of such companies. The purpose of cash flow analysis of a 
firm that is not making profit is to determine its cash availability for continued operational activities. Therefore cash at closing rather than net operational cash flow is a better yardstick. In an attempt to remedy this defect, the following key cash flow ratios are suggested for companies in this situation.

Cash flow adequacy $=$ Cash at year end Total debt

Cash interest coverage $=$ Cash at year end

$$
\text { Total Interest expense }
$$

\section{Summary of Findings}

1. The profitability ratios such as return on equity, return on assets and net profit margin were negative for most of the years between 1993 and 2002. The $U$ test results indicate that the difference between the ROE of PDLI and a major competitor Medimmune Inc. is significant at the 1 percent level. How ever the difference in ROE for PDLI and another major competitor was not significant at any level.

2. The Pearson's correlation coefficient between Protein Design's net sales and R \& D expenditure for the period 1993 to 2002 is .85 and is significant at 1 percent level. Between 1996 and 2002, the annual expenditures on Research and Development exceeded the annual net sales.

3. The current ratio of Protein Design ranges between 10:1 and 58:1 in 1998 and 2000 respectively. Protein Design is by far more liquid than its competitors.

4. The efficiency ratios were poor. They show that during the period, Protein Design had the lowest total asset turnover. It generated $\$ 0.095$ in sales per dollar of assets whereas Corixa generated $\$ 0.2$ and Medimmune $\$ 0.42$. However the results of the $U$ tests indicate that these differences were not significant even at the 1 percent level.

5. Cash flow adequacy and cash interest coverage ratios indicate that Protein Design was extremely liquid for most of the period. Cash flows from financing were responsible for healthy cash flow situation. 
Factors Contributing to the Categorization of Worst Performing Companies

The Case of Protein Design Labs, Inc. (PDLI)

\section{Conclusion}

Protein Design Inc. has invested heavily in Research and Development but has not succeeded in its present research ventures. According to (BTech Investor, 2002) Protein Design Labs' (NASDAQ: PDLI) phase II investigations of Zenapax (daclizumab) have failed to meet their primary therapeutic goal in the treatment of patients with moderate-to-severe psoriasis. Following treatment with the immunosuppressant cyclosporine, administration of Zenapax did not prolong the time to recurrence of psoriasis. These developments do not do the future prospects of Protein Design Inc. justice. The poor profitability efficiency ratios support this. Yet PDLI has continued to maintain a strong balance as evidenced in the very current ration, cash flow adequacy and cash interest coverage ratios. To understand this seemingly diabolical situation, the scale of Protein Design's corporate alliances must be taken into account. First rate emerging biotech companies such as Millennium Pharmaceuticals (MLNM), Human Genome Sciences (HGSI), Protein Design Labs (PDLI) and Vertex Pharmaceuticals (VRTX) all boast of partnerships with major pharmaceutical firms involving payments ranging between $\$ 300$ million and $\$ 800$ million. This is scientific validation by experts, backed up by the steady infusion of cash. Protein Design, in addition to heavy investment in Research and Development, corporate alliances with major pharmaceutical firms, engaged on management reorganization. With a new Chief Executive, a new President of Research and Development, and a strong balance sheet, Protein Design Labs Inc is expecting greater profitability in the future. In teaching Corporate Financial Analysis, situations like this must be highlighted and explained.

\section{References}

Bhandari, S.B. (2003) "Pedagogical issues concerning analysis of the cash flow statement". Journal of Financial Education, 29, spring.

BTech Investor. Press Release, March 21 (2002).http://www.bioportfolio.com/ news/btech_032102_1.htm

Burrill \& Co. February 2002 indices. (2002). http://www.burrillandco.com/ content_pr_indices 03-01-02.html 
Carslaw, C.A. and Mills, J. (1991) "Developing ratios for effective cash flow statement analysis". Journal of Accountancy, 63-70.

Dennis, M.C. (1994) “Understanding cash flow statements". Business Credit, 4042.

Giacomino, D.E. and Mielke, D.E. (1988) "Using the statement of cash flows to analyze corporate performance". Management Accounting, 54-57.

Mills, J. R. and Yamamura, H. J. (1998) “The power of cash flow ratios”. Journal of Accountancy, 53-61.

Multexinvestor. Financial condition ratios. (2003). http://yahoo.multexinvestor.com/ MG.aspx?ticker=PDLI\&y=4\&target=\%2fstocks\%2ffinancialinfo $\% 2$ fratios $\% 2$ ffinancialcondition\& $=13$

Scherer, F.M. (2001) "The link between gross profitability and pharmaceutical R\&D spending”. Health Affairs, 20, Chevy Chase, (Sept/Oct).

Siegel, J. G. and Akel, A. (1989) "A financial analysis and evaluation of the statement of cash flows". The Practical Accountant, 71-78.

Zelle, T. L. and Stanko, B. B. (1994) "Operating cash flow ratios measure a retail firm's ability to pay". Journal of Applied Business Research, 51-59. $\mathrm{G}$ 